Ewa Otomańska

https://doi.org/10.18778/8220-636-4.09

\title{
NOWA PERSPEKTYWA
}

\section{Wstęp}

Tekst dokumentuje cztery pierwsze edycje Międzynarodowego Festiwalu Teatralnego Retroperspektywy oraz edycję specjalną tego festiwalu, która odbyła się pod nazwą: Perspektywy. Wydarzenie, którego organizatorem jest Teatr Chorea i Fabryka Sztuki w Łodzi, ma na celu skonfrontowanie artystów z różnych części świata i poszukiwanie nowych wartości we współczesnym teatrze. Głównym założeniem festiwalu jest spotkanie z drugim, „innym” człowiekiem, podjęcie twórczego dialogu na temat zaproponowanej przez organizatorów problematyki i wymiana doświadczeń między artystami.

Poprzez dialog, jaki w czasie festiwalu prowadzą ze sobą artyści i widzowie, rodzi się wspólnota i zacierają granice między nadawcą a odbiorcą sztuki. Od 2011 roku uczestniczę w działaniach Teatru Chorea - jako widz, wolontariuszka oraz młoda artystka. Nie chcę jednak w tej wypowiedzi wyłącznie „piać pochwalnych peanów" na temat podejmowanych przez organizatora działań, lecz pragnę przyjrzeć się szerzej samemu zjawisku tego festiwalu. W moim tekście chciałabym, opierając się na własnych doświadczeniach, a także na wywiadach z organizatorami, zdać relację z kilku kulturowych perspektyw, jakie w moim przekonaniu otwierają Retroperspektywy/Perspektywy.

Pierwszy zorganizowany przez Chorę Międzynarodowy Festiwal Teatralny Retroperspektywy odbył się w roku 2010. Wydarzenie powstało jako: „[... ] nowe miejsce konfrontacji artystycznych teatru niezależnego” oraz „Platforma spotkań i dyskusji o przemianach zachodzących w teatrze XXI wieku”" Program pierwszego festiwalu stanowił rodzaj podsumowania pięcioletniej pracy Teatru

1 Tomasz Rodowicz, tekst programowy: Festiwal Teatralny Retroperspektywy 2010, http://retroperspektywy.com/pl/o-festiwalu/poprzednie-edycje/retroperspektywy2010/ (dostęp: 10.10.2016). 
Chorea nad zagadnieniami związanymi z kulturą antyku. W swoich spektaklach zespół badał relacje zachodzące między tradycją a współczesnością na przykładach nowej translacji i interpretacji dramatów antycznych Sofoklesa, Eurypidesa i Arystofanesa, a także scenicznej analizy dzieł Zbigniewa Herberta, Stanisława Wyspiańskiego i tekstów Jerzego Grotowskiego. W przedstawieniach, stanowiących rekapitulację różnorodnych działań twórczych grupy, zawarła ona także własny koncept interdyscyplinarnej formy widowiska, które w swoisty sposób łączyło słowo, ruch muzykę oraz własną wykładnię związków łączących tradycję kultury antycznej ze współczesnością.

Angażujący artystów z całej Polski festiwal odbywał się w dniach 13-21 sierpnia 2010 roku w Łodzi. Głównym miejscem rozgrywania się wydarzeń artystycznych były postindustrialne przestrzenie XIX-wiecznych fabryk na Księżym Młynie - zarazem siedziba Teatru Chorea w Fabryce Sztuki przy ul. Tymienieckiego 3. Pozostałe miejsca działań to sale Tv TOYA, Klub Wytwórnia, Akademicki Ośrodek Inicjatyw Artystycznych, Teatr Szwalnia.

Program Festiwalu obejmował dwa tryptyki teatralne: I. Antyczny: Sofokles - Eurypides - Arystofanes i II. Współczesny: Wyspiański - Herbert - Grotowski. W pierwszy tryptyk zostały wpisane takie spektakle jak: Antygona, reż. Dorota Porowska; Śpiewy Eurypidesa, reż. Tomasz Rodowicz; Po Ptakach, reż. Jim Ennis, Jessica Cohen, Tomasz Rodowicz. Drugi tryptyk obejmował: Odpoczywanie, reż. Paweł Passini; Gry w Pana Cogito, reż. Tomasz Rodowicz; Grotowski - próba odwrotu, reż. Tomasz Rodowicz. Prócz spektakli stricte teatralnych zaprezentowane zostały działania usytuowane na pograniczu muzyki i teatru. Były to: Tehi$\mathrm{lim} /$ Psalmy, reż. Paweł Passini, oraz premiera festiwalowa Antyk/Trans/Formacja w opracowaniu muzycznym Tomasza Krzyżanowskiego i Macieja Maciaszka, a choreograficznym Igi Załęcznej i Janusza Adama Biedrzyckiego. W ramach Festiwalu zaprezentowano spektakle osób, które współtworzyły Teatr Chorea, lub też widowiska teatrów, które współpracowały ze Stowarzyszeniem Chorea. Były to m.in. neTTheatre z Lublina ze spektaklami Turandot, Tehilim/Psalmy, reż. Paweł Passini, Studium Teatralne z Warszawy z Król Kier znowu na wylocie, reż. Piotr Borowski, Teatr Kana ze Szczecina z przedstawieniem Lailonia, reż. Mateusz Przyłęcki.

By sprecyzować zamysł artystyczny Festiwalu, warto przywołać słowa jego animatorów i recenzentów. Jak pisał Tomasz Rodowicz, dyrektor artystyczny Festiwalu:

Tworząc Festiwal powołujemy nowe, cykliczne wydarzenie kulturalne, którego kolejne edycje, rozbudowywane o udział wybitnych międzynarodowych grup teatralnych, co 2 lata przełamywać będą anachroniczne podziały na teatr słowa, ruchu 
i muzyki, przywracając ich niepodzielną trójjednię - choreę - życiodajny fundament teatru.

W odniesieniu do naszego festiwalu chorea to nie nazwa własna - lecz idea otwierająca nowe przestrzenie dla teatru i wyznaczająca kolejne zadania dla aktora: opowiadacza historii-tancerza-śpiewaka, i stawiająca nowe wyzwania reżyserowi, który - podobnie jak w antyku - powinien być dramaturgiem, choreografem i kompozytorem jednocześnie.

Zadaniem naszym jest, aby wydarzenie RETRO/PER/SPEKTYWY: CHOREA Festiwal Teatralny stanowiło stały punkt odniesienia na teatralnej mapie Polski i było ważnym ogniwem w staraniach Łodzi o uzyskanie tytułu Europejskiej Stolicy Kultury w 2016 roku.

Tomasz Rodowicz

Dyrektor Artystyczny

Międzynarodowego Festiwalu Teatralnego

Retroperspektywy $2010^{2}$

\section{A Grzegorz Woźniak relacjonował:}

Oprócz wydarzeń artystycznych podczas festiwalu odbywały się także warsztaty, związane z głosem jak np. warsztaty pieśni bułgarskich, pieśni neandertalskie, oraz warsztaty ruchowe $\mathrm{z}$ tańca współczesnego. Odbyło się wiele akcji performance jak: „rekiny i tostery, czyli lekko surrealistyczna opowieść o niebezpieczeństwach” bycia artystą, czy performance Pawła Korbusa. Ciekawym wydarzeniem był panel dyskusyjny z udziałem wybitnych krytyków teatralnych i teatrologów, m.in. Dariusza Kosińskiego, Łukasza Drewniaka, Niny Kiraly, Małgorzaty Leyko, Mariusza Bartosiaka, którzy rozmawiali na temat (retro)perspektyw współczesnego teatru niezależnego. Sam Festiwal został rozpoczęty wystawą autorstwa Pawła Korbusa „Chorea. Poligon ciała i okoliczności”. Festiwal trwał 9 dni, to dużo jak na pierwszą edycję, program był nasycony i różnorodny.

Sam festiwal, organizowany po raz pierwszy, był bardzo ciekawym i wielowymiarowym przedsięwzięciem, obok przedstawień i innych performances odbywały się także warsztaty, obejmujące pracę nad ciałem-ruchem i głosem. Miałem możliwość brania udziału w warsztatach pieśni bułgarskich, prowadzonych przez Eline Tonevę.

2 Tomasz Rodowicz, http://www.chorea.com.pl/pl/festiwal/nowa-strona/ (dostęp: 10.10.2016) [zob. też: wypowiedź Tomasza Rodowicza na temat Festiwalu w: To, co w nas ciemne, ulega prześwietleniu. Pierwsze piętnaście lat Teatru Chorea, red. Maja Wójcik, Stowarzyszenie Teatralne Chorea, Łódź 2019, s. 209 - przyp. red.] 
Było to bardzo niezwykłe doświadczenie pracy z głosem i muzyką tradycyjną, z całkowicie innej przestrzeni kulturowej ${ }^{3}$.

Retroperspektywy 2010 to także czas podejmowania przez aktorów Teatru Chorea pierwszych indywidualnych działań artystycznych. Najważniejsze z nich i znaczące dla rozwoju tak artystów, jak i całego zespołu to: Upadek Psycho Somatic Gay-m, monodram Janusza Adama Biedrzyckiego w reż. Magdaleny Paszkiewicz, który zapoczątkował stałą współpracą twórców w następnych latach; Niedorodzona w reż. Anny Ciszowskiej - z udziałem Julii Jakubowskiej; Koncert Antyk/Trans/Formacja, widowisko muzyczno-taneczne autorstwa Tomasza Krzyżanowskiego, w aranżacji muzycznej Macieja Maciaszka oraz choreografii Igi Załęcznej i Janusza Adama Biedrzyckiego. Warto przytoczyć wspomnienie tego artysty, który towarzyszył narodzinom Festiwalu i współtworzył jego kolejne edycje:

Sięgam pamięcią i widzę spotkanie ludzi, którzy przez wiele lat wspóttworzyli Choreę, niektórzy ją zakładali, ale poszli swoją ścieżką, drogą teatralną. Pamiętam tę pierwszą edycję Retroperspektyw jako intensywny czas pracy; był to nasz pierwszy festiwal, pierwsze takie dziecko, które dopiero się rodziło. Brałem wtedy udział w wielu spektaklach prezentowanych podczas festiwalu: Śpiewy Eurypidesa, Gry w Pana Cogito, Antygona, Koncert Antyk/Trans/Formacja, i na końcu mój pierwszy indywidualny projekt - Upadek Psycho - Somatic-Gay-m. Patrząc w przeszłość - to było czyste szaleństwo, bo prócz wydarzeń artystycznych była jeszcze praca organizacyjna. Jednak ludzie, czas, miejsce to na zawsze zostanie w moim sercu jako rodzaj wspaniałego święta, misterium. Większość wydarzeń odbywała się w naszych fabrykach jeszcze przed ich generalnym remontem, więc wiele akcji czy spektakli odbyło się w bardzo dziwnych przestrzeniach, które były dalekie od miejsc zwanych teatrem, ale to tylko podniosło ich rangę. Spotkania i prezentacje swoich spektakli ludziom tak bliskim - to było niesamowite. Bardzo się cieszę, że Festiwal RETROPERSPEKTYWY doczekał się już 5. edycji, jest to kolejny ważny punkt na mapie kultury w Polsce, a przede wszystkim w Łodzi. Miejsce spotkań ludzi widzących podobnie, a jednak inaczej ${ }^{4}$.

Aby jeszcze lepiej zrozumieć, czym dokładnie był (i jest) festiwal Retroperspektywy, i co kierowało jego twórcami, którzy pragnęli zainicjować w Łodzi zupełnie nowe teatralne święto, zdecydowałam się porozmawiać z dyrektorem

3 Grzegorz Woźniak, Retro/per/spektywy [dział: Czasopisma, Festiwale, Nagrody, Lamus, Życie Literackie], „Lampa” 2020, nr 10.

4 Tekst Janusza Adama Biedrzyckiego udostępniony za zgodą Autora wypowiedzi. 
Teatru Chorea Tomaszem Rodowiczem i uczynić tę rozmowę ważnym elementem mojej wypowiedzi.

\section{Wywiad z Tomaszem Rodowiczem ${ }^{5}$}

Ewa Otomańska: Zacznijmy od początku. Gdy Chorea po raz pierwszy zdecydowała się stworzyć festiwal, była świeżo po zakończeniu swojej wędrówki. Po znalezieniu własnego miejsca w Łodzi, bardzo szybko zaczęła eksplorować miasto. Co było dla Chorei impulsem do stworzenia festiwalu w mieście, do którego tak niedawno przybyliście? Dlaczego właśnie Łódź? Czy nie wiązało się to z dużym ryzykiem?

Tomasz Rodowicz: Oczywiście, że ryzyko było duże, ale chcieliśmy dać o sobie znać w mieście, zaznaczyć jakoś naszą obecność. Oprócz tego już od pewnego czasu pragnęliśmy stworzyć miejsce spotkań, w którym każdy będzie mógł swobodnie uczestniczyć. Po przeszukaniu wielu miejsc i jeżdżeniu po całej Polsce Łódź okazała się najciekawszym miejscem do pracy dla naszego teatru oraz dla tego, co myślimy o teatrze Stąd decyzja, nie tylko moja, ale kilku osób z zespołu Chorei, żeby właśnie tu przenieść się na stałe. To był ważny życiowy wybór i uważam, że ze wszystkich możliwości, ze wszystkich miejsc, w których mogliśmy zakotwiczyć, to było najlepsze; to była dobra decyzja, a może nawet najlepsza ze wszystkich.

Chcieliśmy robić festiwal dlatego, żeby mieć szansę i możliwość spotkania z tym wszystkim, co się działo wokół nas. Spotkania wszystkich teatrów czy grup muzycznych, teatralnych, tanecznych, które - jak sądziliśmy - robią coś ciekawego, a które nie mają możliwości właśnie się spotkać. Chcieliśmy stworzyć możliwości wymiany doświadczeń i zainspirowania się nawzajem, dlatego na naszym festiwalu nie koncentrujemy się na znanych już w Polsce artystach. Skupiamy się raczej na tych grupach, które nie jeżdżą po festiwalach, nie są rozpoznawalne dzięki wielkim nazwiskom artystów, ale są to takie zespoły, które robią rzeczy ciekawe, nowe i w jakiś sposób się wyróżniają. Organizując festiwal, działamy cały czas w imię szukania jakiegoś nowego - żywego - języka teatru, który powinien być jakoś wyraźnie określony w tej zmieniającej się rzeczywistości. Wydaje mi się, że szukać należy cały czas na nowo, po to, by móc dotrzeć do widza jak najmocniej. By ludzie, którzy przychodzą obejrzeć spektakl, mogli czegoś prawdziwego doświadczyć. By to, co wydarza się w teatrze, a co zostaje później w widzu, różniło się od filmu, telewizji, kabaretu i tego wszystkiego, co w klasycznym teatrze się dzieje. Na festiwalu chcemy prezentować grupy, które mają odwagę pokazać to, czego ludzie nie chcą oglądać, ale też takie, które odważnie podążają za

5 Wywiad przeprowadzony przez Ewę Otomańską z Tomaszem Rodowiczem w 2016 roku, udostępniony za zgodą Autora wypowiedzi. 
eksperymentem w sztuce, są nastawione na poszukiwanie, stwarzanie pewnego kontekstu dla swojej działalności.

EO: Od pierwszej edycji festiwal stawiał nie tylko na spektakle polskie, ale też na międzynarodowe? Dlaczego Chorei tak zależy na zagranicznych gościach?

TR: Tak. To dlatego, że uważamy, iż w teatrze na świecie dzieją się równie ciekawe rzeczy, jak w teatrze polskim. Co więcej, taka międzynarodowość festiwalu zawsze daje jeszcze szerszą perspektywę kulturową, szerszy kontekst prezentowanych zjawisk.

EO: Skąd nazwa Retroperspektywy? W jaki sposób oddziałuje ona na program festiwalu?

TR: Retroperspektywa oznacza, z założenia, poruszanie się w obszarach między tradycją a nowoczesnością oraz tym, co w przyszłości. Nazwę, jak i główne założenia festiwalu, można rozłożyć na „retro” - czyli szukanie: w przeszłości i w tradycji, oraz na „perspektywę” - taką przestrzeń, jaką stwarza teatrowi jego nowe odczytanie. Jedną z dziedzin działań Chorei jest eksploracja tego, co antyk może nam powiedzieć dzisiaj (i jutro), nie poprzez rekonstrukcję tego, co przeszłe, ale przez tworzenie własnego języka - na bazie inspiracji i pytań zadawanych $\mathrm{z}$ tamtej strony.

EO: No tak, bo każda edycja opiera się na kolejnych składnikach Chorei ${ }^{6}$. A co, gdy skończy się liczba i ekspresja muz? Czy wówczas od początku zaczniemy przyglądać się kolejnym zagadnieniom antycznej trójjedni w nowym świetle? Czy będziemy szukać nowych wyzwań?

TR: Tego jeszcze nie wiem, tak daleko nie sięgam. Na razie mamy zaplanowane dwie kolejne edycje, a później zadamy sobie pytanie, co robić dalej. Nie będziemy na pewno nic „wymyślać”, nie będziemy tworzyć „nowych - antycznych jakości”. Raczej będziemy chcieli iść za tym, co jest żywą potrzebą teatru i komunikatu w teatrze, czy co wynika z potrzeb młodego pokolenia. Dlatego, że festiwal jest w dużym stopniu kierowany do młodych ludzi, którzy dopiero zaczynają robić teatr. Chcemy, żeby odnajdywali się w nim jak najlepiej, więc kolejne ewolucje, jakie nasz festiwal będzie przechodził, są w pełni zależne od relacji, w jakiej teatr i widz zostaną wobec siebie postawieni. Zatem tego, jakie będą kolejne hasła i ścieżki tematyczne festiwalu, dziś przewidzieć nie mogę.

6 CHOREA to - zgodnie z utrwalonym kulturowym przekonaniem - harmonijna integracja trzech podstawowych środków ekspresji artysty teatru, znanych z historii antycznego teatru greckiego. Określa ona sposób funkcjonowania: słowa, muzyki i ruchu - w działaniu pojedynczego aktora, a także grupy aktorów. 
EO: W roku 2015 mieliśmy możliwość uczestniczenia w mniejszym Festiwalu Perspektywy ${ }^{7}$. Czy to było jednorazowe wydarzenie, czy też możemy liczyć na to, że już zawsze - w latach pomiędzy dużym festiwalem Retroperspektywy - będziemy mogli cieszyć się małymi Perspektywami?

TR: W tej chwili nie umiem odpowiedzieć na to pytanie. Organizacja tego wydarzenia wiąże się z ogromnym wysiłkiem całego naszego zespołu, a także biura - przez cały rok. Ale chcemy znaleźć formułę organizacji pewnych mniejszych przeglądów i spotkań. Planujemy rozłożyć małe Perspektywy na cykl kilku wydarzeń w roku, które pozwoliłyby zaprosić najciekawsze zespoły teatralne w Polsce. Te, które są właśnie tym nietypowym teatrem - rodzącym się z potrzeby wyrażania siebie przez teatr, a nieskupiającym się na zawodowstwie. Interesują nas teatry, które szukają za pośrednictwem sztuki sposobu wyrażania i manifestowania swojej inności, poruszają się w pozornie wykluczonym i dysfunkcyjnym świecie teatru, w którym często może być zawarte wielkie bogactwo doznań współczesnej estetyki i humanistyki.

EO: Chciałabym zapytać o kontekst osadzenia festiwalu w przestrzeni miasta. Podczas każdej edycji, od początku festiwalu, teatr wychodził do widza - w wielu swoich działaniach. Czy fakt oddania do użytku w roku 2014 Art_Inkubatora ${ }^{8}$, który stał się centrum festiwalu, wplynął na to miejskie oddziaływanie?

TR: Nie chciałbym się wiązać tylko z taką relacją ani definiować wyłączne przez pryzmat miejskich interwencji teatralnych, choć w ramach festiwalu często podejmowane są $\mathrm{w}$ obszarze miasta akcje promocyjne czy działania towarzyszące. W 2016 mieliśmy np. wydarzenie Pieśni dla miasta, które dotykało różnych miejsc w Łodzi, ale i takie praktyki artystyczne mają na celu zapraszanie widzów do naszego gniazda. Gniazda, które chcemy bardzo mocno ustanowić jako centrum działania i tygiel różnych myśli teatralnych. Na stałe nie można sobie określić jednego ustalonego kierunku działania. Łódź zawsze będzie dla nas miastem żywym i będziemy bezustannie wchodzić w jego przestrzeń, i wychodzić z niej. Zawsze wówczas, gdy będziemy mieli konkretną rzecz do zadziałania, konkretne pytanie do zadania, które trzeba skonfrontować z odbiorcami. Myślę, że przyszłość pokaże nam jeszcze takie możliwości.

EO: Co mnie najbardziej porusza w Retroperspektywach, to fenomen dokonującego się tu spotkania i forma, w jakiej publiczność może prowadzić otwarty

7 Festiwal Retroperspektywy odbywa się co dwa lata. Perspektywy byly edycją specjalną tego festiwalu, która odbyła się w latach pomiędzy dwiema głównymi odsłonami.

8 Art_Inkubator to zrewitalizowany ze środków unijnych obiekt stanowiący część dawnej jurydyki przemysłowej Karola Scheiblera, który obejmuje trzy budynki pofabryczne. Jest to instytucja kulturalna stworzona w 2007 roku z inicjatywy Łódź Art Center i Stowarzyszenia Teatralnego Chorea. 
dialog z artystami. Wymiana emocji i myśli, jaka się w ten sposób nawiązuje, jest niezwykła; bardzo rzadko można mieć okazję do zawiązania tak bliskich relacji między aktorem a widzem. Tak otwarta forma spotkania zapewnia komfort i zachęca widza do wyrażania swojego zdania. Co festiwal daje artystom, a co zabiera ze sobą? W jaki sposób wykorzystać można spotkanie na festiwalu?

TR: Każdy indywidualnie - na swój własny sposób. Wydaje mi się, że najważniejsze jest to, żeby festiwal wrócił do tej pierwotnej formy spotkania grup ludzi, którą stanowi wymiana. Tak, żeby zespół, który przyjeżdża na festiwal, miał szansę zobaczyć inne produkcje, i równocześnie, żeby mistrzowie w swoich dziedzinach (z poszczególnych grup) mogli poprowadzić warsztaty i podzielić się swoimi umiejętnościami ze wszystkimi chętnymi. Ważne jest dla mnie, by mieli możliwość zainspirować uczestników warsztatów, którzy na ogół będą pochodzić $\mathrm{z}$ młodych zespołów działających w teatrach w mieście. Myślę, że będę bronił takiej właśnie formuły festiwalu, choć jest ona dość trudna do udźwignięcia - zarówno organizacyjnie, jak i finansowo. Trzeba na przykład przez trzy dni utrzymać dużą grupę osób oraz zapewnić wszystkim noclegi. Mimo to wydaje mi się, że będę dążyć do tego, by ta formuła festiwalu była jak najbardziej otwarta, by był on miejscem spotkania, dialogu i inspiracji. Miejscem wspólnych radości, poczucia, że teatr jest przede wszystkim wspólnotą ludzi twórczych, którzy chcą przez bezpośrednie spotkanie człowieka z człowiekiem szukać inspiracji. W ramach naszego festiwalu zapraszamy widzów i artystów do wspólnych poszukiwań. Konfrontujemy naszych gości z pytaniami, jakie dziś stawia wobec nas teatr, a to właśnie on - przez sztukę - uczy umiejętności odpowiadania sobie na trudne pytania.

EO: W takiej formie festiwal staje się rodzajem laboratorium, w którym widzowie są poddawani eksperymentom teatralnym mającym na celu znalezienie wspólnego języka. Jednocześnie teatr staje się przestrzenią dialogu, wolną od schematycznego pojmowania widowiska teatralnego.

TR: Tak, chcemy by utworzyła się pewna sieć wymiany. Festiwal staje się wtedy areną komunikacji i budowania jakichś nowych działań. Staje się przestrzenią tworzenia nowych wydarzeń artystycznych i to może zaistnieć wtedy, gdy ludziom dane będą miejsce i czas. Festiwal daje rzadką okazję, by w jednym miejscu, od rana do wieczora, ludzie mogli przebywać ze sobą, uczestniczyć w warsztatach, chodzić na spektakle, wymieniać się poglądami i dyskutować.

EO: W tej sytuacji perspektywa poszerza się o kolejne kręgi i festiwal udowadnia, że język teatru jest tak uniwersalny, że właściwie zupełnie nieważne jest, z którego kraju się przyjeżdża i z jakiej kultury się pochodzi - i tak można się dogadać i stworzyć razem coś wspólnego, zawieszonego ponad wszelkimi podziałami. Wielokrotnie podkreślasz, jak ważna jest dla ciebie, jako gospodarza festiwalu, wymiana, wzajemna inspiracja i oddziaływanie na siebie grup z całego świata. Czy dla ciebie wymarzoną wypadkową tych wszystkich spotkań byłoby 
stworzenie „hybrydy” dwóch grup ludzi, którzy spotkali się na festiwalu i stworzyli coś własnego, dużo bardziej różnorodnego, niż można by pierwotnie zakładać, i przenikającego się? Coś, co zaistniałoby ponad wcześniejszymi podziałami?

TR: Nie wiem. Ja uważam, że nie warto zakładać jakiegoś wymarzonego spotkania - ideału - i nie warto kreować jego obrazu. Chciałbym za każdym razem przede wszystkim iść za tym, co się wydarza - ciekawego, żywego. Nie mam ambicji, by doprowadzić do idealnego spotkania, ani nadziei, że to może się udać. Raczej szukam tego, co wyjątkowe w tych bardzo wielu różnych wypowiedziach, które tu się spotykają, zakładając, że każdy stworzy własną, inną drogę ku spotkaniu i zainspiruje nią także mnie. Bo jakbym do końca wiedział, czego naprawdę chcę i dokąd mam dojść, to bym nie musiał już tego robić...

\section{O tematyce poszczególnych edycji}

Teatr jako instytucja niezwykle czuła na zmiany społeczne, powinien stale oddziaływać na otaczającą go rzeczywistość i pełnić funkcje swoistej „antytoksyny" w trudnym czasie. Zadanie współczesnego teatru nie powinno ograniczać się do roli stwarzania widzom fantastycznego i odrealnionego, izolującego od rzeczywistości „schronu”. Teatr powinien raczej uczulać widza na role, które powinien on - czy mógłby - pełnić w rzeczywistości, i proponować mu drogi, dzięki którym zintegruje się z otaczającym go światem. Teatr, który wychodzi widzowi naprzeciw i nie boi się zadawać mu pytań trudnych, to teatr przekraczający granicę. Organizując Festiwal, zespół Chorei zawsze stara się skonfrontować swoją publiczność z tym, co trudne, i z tym, co zdaje się wykraczać poza nasze tradycyjne myślenie o teatrze. Każda z kolejnych edycji wydarzenia jest hasłowo ukierunkowana na wybrany obszar takiej niekonwencjonalnej i twórczej przestrzeni spotkania, co znajduje wyraz w temacie przewodnim Festiwalu, będącym także „nicią ideową" całego repertuaru.

\section{Teatr żywy, a nie mityczny}

Tematem organizującym pierwszą Retroperspektywę było poszukiwanie związków między antykiem a współczesnością. Odpowiadając na to wyzwanie, swoje spektakle zaprezentowali organizatorzy oraz zaprzyjaźnione teatry z terenu Polski. Z edycji na edycję festiwal się rozrastał i stawał się coraz bardziej międzynarodowy. Poszerzanie perspektywy kulturowej, budowanie różnorodnych 
relacji między zapraszanymi artystami stawało się procesem skłaniającym ich do formułowania odpowiedzi na pytania stawiane przez Choreę. Wraz z rozwojem teatru i jego coraz silniejszym zaangażowaniem w ogólnopolskie i międzynarodowe projekty, sieć kontaktów zagęszczała się, a wspólne działania zaczęły dotykać coraz trudniejszych mentalnie, etycznie i artystycznie zagadnień. To, jak ważna jest dla wszystkich artystów i organizatorów Festiwalu identyfikacja z jego przesłaniem, ujawnia już stopień ich osobistego zaangażowania w wydarzenie - nie tylko w jego przygotowanie, ale także w samo uczestnictwo w festiwalu. Jako gospodarze zespół Chorei co roku przygotowuje przynajmniej jedną festiwalową premierę; organizuje też własne warsztaty, ale przede wszystkim wszyscy członkowie grupy każdego dnia podczas trwania Festiwalu są na nim obecni. Artyści dzielą się z gośćmi swoim czasem, przestrzenią i pracą, a także prywatnymi historiami. Podczas pierwszych Retroperspektyw oficjalnym logotypem i maskotką festiwalu stała się postać psa Zenona ${ }^{9}$, którego właścicielem był dyrektor teatru Chorea, Tomasz Rodowicz. Fakt ten dowodzi nie tylko poczucia humoru organizatorów i zachowania dystansu wobec własnych działań, ale jest też widomym znakiem wagi, jaką twórcy teatru przypisują mu w życiu prywatnym, ujawnia, jak silnie teatr przenika wszystkie obszary ich aktywności i emocji. Artyści Chorei nie pracują „od - do”. Nie oddzielają grubą kreską życia prywatnego od budowania tego życia na scenie. Pozwalają, by te dwie sfery rzeczywistości się przenikały, tworzą prawdziwą wspólnotę. Wszyscy angażują się w sprawy organizacyjne i wolontariat, razem budują przestrzeń, do której pragną zaprosić widza. Tak jak deklarowali organizatorzy Festiwalu w czasie jego pierwszej edycji: Retroperspektywy stały się ważnym punktem odniesienia na teatralnej mapie Polski, a także ważnym ogniwem życia kulturalnego Łodzi. Podsumowując atmosferę panującą na pierwszej edycji festiwalu, sięgnę po wypowiedź Pauliny Ilskiej:

Osobisty, mocny ton Retro/Per/Spektyw niewątpliwie zapada w pamięć. Z widzami nikt $w$ ten sposób teraz nie rozmawia. Serwuje się rozrywkę, przedstawienia mile ładne albo alternatywnie brzydkie, wreszcie ambitne, czyli nudne i przygważdżające do ziemi... Chorea zmusza nas do czegoś zupełnie innego - do obcowania z nowym, pulsującym życiem językiem teatralnym, do zaangażowania emocjonalnego, do wnikliwego przeczytania lektur, o których się sądziło, że się je doskonale zna ${ }^{10}$.

9 Pies Zenon - oficjalny członek i wierny przyjaciel zespołu Chorea. Grał w spektaklu Szczeźli Pawła Passiniego, w towarzystwie swojego właściciela - Tomasza Rodowicza.

10 Paulina Ilska, Stawiać widza przed ściana, „Arterie” 2010, nr 2. 


\section{Teatr koszerny}

Druga edycja Retroperspektyw nawiązywała w dużym stopniu do tradycji i kultury żydowskiej. Artyści tworzyli widowiska, opierając się na własnych doświadczeniach i kreując $w$ ten sposób dzieła niepowtarzalne i odcinające się od stereotypowych ujęć. Operując różnorodną estetyką i metodami pracy, próbowali dotrzeć do sedna własnego stanowiska wobec zjawiska, jakim jest wpływ kultury żydowskiej na polską rzeczywistość, oraz ujawnić współczesne funkcjonowanie tej kultury. Widzowie i twórcy mieli możliwość konfrontacji z dorobkiem tej niegdyś jednej z najliczniejszych spośród narodowości mieszkających w Łodzi i ustosunkowania się do dzisiejszych wyobrażeń na ten temat ${ }^{11}$.

Zagadnienie ma tak wielką wagę - dla wewnętrznego rozwoju Festiwalu oraz dla faktu usytuowania go w Łodzi - że zdecydowałam się w tym miejscu przytoczyć duży i ważny fragment wypowiedzi programowej Tomasza Rodowicza, w której wyjaśnia on powody podjęcia tego tematu i syntetycznie przedstawia festiwalowe wydarzenia służące jego interpretacji:

Żydostwo w sztuce i w życiu krąży wokół mnie od lat. Na różne sposoby próbowałem się dystansować i obronić przed tym, co sentymentalne i tragiczne, ale ten temat osaczał $i$ angażował mnie coraz bardziej poprzez spotkania z takimi artystami jak Passini, Gamson czy Osterman. Uznałem, że nadszedł czas, aby te doświadczenia zebrać i zderzyć ze sobą. Okazuje się, że tu nie chodzi o mnie, tylko o każdego $\mathrm{z}$ nas. Tym, co łączyło wszystkie prezentowane podczas tego festiwalu spektakle była próba konfrontacji i zdefiniowania siebie wobec przeszłości oraz wobec własnych marzeń i lęków.

Mieliśmy możliwość wybrania się w wielopoziomową podróż - opowieść o żydowskich przodkach i niemieckich eksperymentach genetycznych - podczas polskiej premiery spektaklu TOV, przygotowanej przez wybitną choreografkę Rosannę Gamson z Los Angeles i zespół CHOREI. Młoda reżyserka z Tel Avivu Ruthie Osterman zrealizowała interdyscyplinarny projekt Szpera 42, odwołujący się do najbardziej dramatycznych wydarzeń łódzkiego getta - wielkiej wywózki do obozów zagłady 15 tysięcy dzieci i starszych ludzi we wrześniu 1942 roku. Paweł Passini w premierowej Księdze Blasku w przewrotny sposób sięgnął po jedną z najbardziej zagadkowych ksiąg ludzkości - Kabałę, za pomocą której próbuje prześwietlić całą swoją dotychczasową drogę w teatrze. Natomiast teatr Manisha Mitry z Indii przedstawił Podróż do Daakghar, szkatułkowy spektakl o Januszu Korczaku pracującym $\mathrm{z}$ dziećmi nad sztuką $\mathrm{R}$. Tagore w przeddzień wywózki do Oświęcimia.

11 [W początkach XX wieku ludność żydowska stanowiła ponad 30\% mieszkańców Łodzi, zob. artykuł Sebastiana Szajnera w tym tomie - przyp. red.] 
Premierowy spektakl pt. Rok 2012 - efekt ponad dwumiesięcznej współpracy artystów z Białorusi z aktorami CHOREI pod kierunkiem Doroty Porowskiej i Ewgienija Korniaga - był próbą zdefiniowania miejsca młodego obywatela wschodniej Europy we współczesnym świecie. Wieloznaczną opowieść o męskich słabościach zobaczyliśmy w duńskim spektaklu Men \& Mahler stworzonym w wyniku współpracy międzynarodowej grupy artystów należących do sieci DNA Continuum. W ramach prezentacji łódzkiej sceny zaproponowaliśmy spektakl Teatru Pinokio - Bruno Schulz, w reżyserii Konrada Dworakowskiego oraz Re:akcję Pracowni Fizycznej prowadzonej przez Jacka Owczarka.

Drugim filarem festiwalu była scena muzyczna w Willi Grohmana, gdzie mieściło się nasze Centrum Festiwalowe. Zagrali dla nas m.in.: The Blue Rabbit z Łodzi, skład SzaZaZe i Chór Gre Badanie z Warszawy, międzynarodowa formacja The Turbans z Londynu, czy grający muzykę bałkańską zespół Sarakina z Białegostoku. Szczególnym wydarzeniem festiwalu był koncert Pieśni Świata w wykonaniu Wielkiego Chóru Młodej CHOREI, pod kierownictwem Tomasza Krzyżanowskiego. Była to kontynuacja pracy edukacyjnej podjętej podczas naszego największego projektu Oratorium Dance Project.

Festiwal dopełnił cykl różnorodnych warsztatów teatralnych i muzycznych prowadzonych przez artystów z całego świata.

Celem naszego festiwalu jest spotkanie niepokornych artystów, którzy działają w obrębie tego samego kręgu niewygodnych pytań filozoficznych, społecznych i antropologicznych. W perspektywie gwałtownego przyspieszenia cywilizacyjnego, totalnej komercjalizacji naszej wyobraźni i gubienia europejskiej tożsamości, o której alarmuje Zygmunt Bauman, chcemy gromadzić wokół naszego festiwalu twórców, których najważniejszą ideą jest pytanie o tożsamość jednostkową i społeczną, o granice naszej wrażliwości i pamięci oraz wartości uzasadniające sens i cele naszego działania12.

\section{Sztuka, która promieniuje}

Kolejna, trzecia edycja wydarzenia, która odbywała się w roku 2014 i trwała od 21 do 25 sierpnia, przebiegała pod hasłem „Sztuka Promieniuje”. Ideą tego Festiwalu było uświadomienie odbiorcom (i sobie) potrzeby zniesienia granic między różnymi, wyznaczanymi dziś kategoriami czy gatunkami teatru oraz uchwycenie

12 Tomasz Rodowicz, Retroperspektywy 2012 [wypowiedź programowa na temat Międzynarodowego Festiwalu Teatralnego Retroperspektywy 2012], strona Festiwalu, http:// retroperspektywy.com/pl/o-festiwalu/poprzednie-edycje/retroperspektywy2012/ (dostęp: 10.10.2016). 
zasady społecznego oddziaływania teatru w dzisiejszej rzeczywistości. Twórcy tej edycji Festiwalu pragnęli udowodnić, że współczesność niweluje tradycyjny sposób klasyfikowania teatru za pomocą konwencji, jakie zdaje się on reprezentować. Według Tomasza Rodowicza jedyne uzasadnione, aktualne i faktycznie istniejące rodzaje teatru, jakie warto wyznaczać, to: „teatr żywy” i „teatr martwy”.

Festiwal przez obecność tak różnorodnych artystów udowodnia, że teatr słowa, teatr tańca, teatr muzyki... nie ma już najmniejszego sensu. Ten podział jest już anachronizmem w sztuce. Wszystko jest teatrem żywym albo martwym. I każdy teatr w równej mierze powinien posługiwać się słowem, muzyką i ruchem. Może różnie akcentować te trzy środki komunikacji z widzem, ale pełnię życia uzyskuje, gdy wszystkie trzy mówią naraz z tą samą siłą ${ }^{13}$.

Taka perspektywa rozumienia teatru - jako zjawiska wolnego od podziałów na kategorie, za to zależnego w pełni od emocjonalnego zaangażowania widza i szczerości intencji aktora - przypomina nieco słynny koncept (i deklarację) pojmowania teatru przez Jerzego Grotowskiego: „wierzę, nie wierzę"14. Postawę tę (i replikę kierowaną do artystów) Grotowski przejął od Konstantina Stanisławskiego. Podejście takie jest wyrazem przekonania, że tworzenie kategorii jest w pełni zależne od wyboru oraz woli widza i odnosi się do jego poczucia estetyki i naturalnej empatii. „Sztuka, która promieniuje” jest tą, która przez swoje oddziaływanie na widza pozostawia go innym, niż go zastała, dokonuje w nim zmiany. Według organizatorów Festiwalu teatr ma nadzwyczajną moc takiej zmiany, jest w stanie - jak żadna inna sztuka - poruszać, nauczać, a także wskazywać drogę.

Chorea w czasie swojej działalności teatralnej często oddawała się swego rodzaju „pracy u podstaw”. Czyniła to za pomocą prowadzenia edukacyjno-artystycznych warsztatów w środowiskach defaworyzowanych czy też organizowanie długofalowych projektów mających - wprawdzie nie bezpośrednio, ale przez działania artystyczne - zawierać w sobie funkcje terapeutyczne. Artyści podejmujący tego rodzaju praktyki często podkreślają, że ich celem nie jest przeprowadzenie teatroterapii, ale danie sobie wspólnie czasu na powstanie procesu, w którym pod wpływem podjętego działania artystycznego i pracy włożonej w tworzenie spektaklu zachodzi głęboka

13 Tomasz Rodowicz, Retroperspektywy 2014 [wypowiedź programowa na temat Międzynarodowego Festiwalu Teatralnego Retroperspektywy 2014], strona Festiwalu, http:// retroperspektywy.com/pl/o-festiwalu/poprzednie-edycje/retroperspektywy2014/ (dostęp: 10.10.2016).

14 Jerzy Grotowski, Teatr jest spotkaniem, [w: ] idem, Ku teatrowi ubogiemu, przeł. $\mathrm{z}$ ang. Grzegorz Ziółkowski, red. Leszek Kolankiewicz, Instytut im. Jerzego Grotowskiego, Wrocław 1968. 
przemiana we wszystkich uczestnikach wydarzenia. Chorea rozumie zasadę oddziaływania teatru na odbiorcę bardzo szeroko: od wywoływania wzruszeń, przez skłanianie go do przemyśleń nad sytuacją, z jaką jest konfrontowany podczas spektaklu, po czynne angażowanie widza w amatorskie działania teatralne, które mogą stać się dla niego sposobem na wyrażanie siebie - poprzez sztukę teatru i wobec niej.

Trzecia edycja Festiwalu Retroperspektywy stała się również podsumowaniem dziesięciu lat funkcjonowania zespołu i pracy artystów Chorei. Znów warto oddać głos liderowi grupy. Tomasz Rodowicz konstatuje:

Minęło jak jeden obrót księżyca, jak łyk dobrego wina.

Byliśmy na początku razem i nie znaliśmy siebie ani swoich marzeń. Dziś jesteśmy razem, ale każdy już też gdzie indziej. Umiemy poznawać swoje marzenia i przeistaczać je w materię spektakli. To jakiś cud utrzymać w tym chaosie i totalnej anarchii przez tyle lat konsekwencję i kierunek, znaleźć własny język i tyle się dowiedzieć o ludzkiej naturze. [...] Ciągle zaczynamy od nowa i ciągle ważniejsze jest to, co na horyzoncie przed nami niż to, co na plecach i w smudze cienia. Nie mamy żadnego dorobku, bo teatr staje się tylko na chwilę, w tym jednym momencie spotkania $\mathrm{z}$ widzem i potem go nie ma. [...] A tak naprawdę jedynym dorobkiem dziesięciu lat tej grupy jest niegasnące poczucie humoru, pełne zaangażowanie i całkowity brak dystansu w działaniu i w procesie zwanym twórczym oraz totalny dystans w stosunku do siebie, własnych słabości i słabości kolegów.

I wiemy, gdzie iść 15 .

Wraz z dojrzewaniem teatru festiwal staje się coraz bogatszy, pogłębiony o różnorodne doświadczenia jego twórców. Perspektywa (artystyczna, mentalna, światopoglądowa) nieustannie się rozszerza, a publiczność - przynajmniej tak długo jak Chorea będzie się rozwijać - może liczyć na rosnący, z każdym kolejnym festiwalem, poziom wydarzenia.

\section{Bliższe Perspektywy}

Rok 2015 przyniósł widzom niespodziankę w formie nadzwyczajnej aranżacji festiwalu, który została przeprowadzony w czasie pomiędzy odbywaniem się głównych edycji wydarzenia. Festiwal Perspektywy - teatr poza teatrem, trwał od 7 do 10 maja i był poniekąd kontynuacją głównego festiwalowego nurtu, jaki

15 Tomasz Rodowicz, 10 Lat Chorei... [wypowiedź na temat Międzynarodowego Festiwalu Teatralnego Retroperspektywy 2014], strona Festiwalu, http://retroperspektywy. $\mathrm{com} / \mathrm{pl} /$ o-festiwalu/poprzednie-edycje/retroperspektywy2014/ (dostęp: 10.10.2016). 
stanowią Retroperspektywy. Wydarzenie, tak jak jego odbywający się cyklicznie festiwal-matka, posiadał wspólny wątek ideowy łączący wszystkie rodzaje podejmowanych w jego trakcie aktywności. Tym razem hasłem przewodnim Festiwalu było zagadnienie inności i wykluczenia. Rodowicz podsumowywał:

Ta edycja festiwalu była spotkaniem artystów, którzy chcą zmieniać rzeczywistość wokół siebie. Wychodzą poza teatr, poza mury instytucji kultury, aby szukać nowego tworzywa teatru i nowego języka w komunikowaniu się z widzem. Praca w kontekście dysfunkcji społecznych, umysłowych czy fizycznych skłania do stawiania pytań o „normalność” i jej ukryte pułapki. Chcemy, by spotkanie tak pracujących grup posłużyło współuczestnictwu, współtworzeniu i wymianie myśli, metod i technik pracy. Aby droga, którą przejdą uczestnicy festiwalu ułożyła się w następujący sposób: SPOTKANIE - PREZENTACJA - INSPIRACJA - WYMIANA - KONTYNUACJA - TWORZENIE SIECI.

Pokazując najciekawsze zjawiska spoza oficjalnego nurtu chcemy zainteresować i pobudzić zarówno twórców teatralnych, uczestników projektów, jak i widzów do dzialań w kontekście społecznym i w tej przestrzeni tworzyć wspólnie nowy język teatru ${ }^{16}$.

Podczas tej wyjątkowej edycji rozmawialiśmy przede wszystkim o tym, co teatr może dać każdemu z nas, oraz w jaki sposób wykorzystać można narzędzie teatru w pracy nad przekraczaniem własnych granic: społecznych, mentalnych, poznawczych, emocjonalnych. Gośćmi festiwalu były grupy artystów na co dzień postrzegane i klasyfikowane jako zespoły reprezentujące postawę identyfikowaną w polskiej refleksji nad teatrem (za sprawą konceptu Lecha Śliwonika) - jako "teatr dla życia”" ${ }^{17}$. W większości mieliśmy tu do czynienia z młodymi twórcami teatru podejmującymi próbę wyrażenia siebie na scenie bez ukrywania swojej „inności”. Byli to artyści borykający się często z sytuowaniem ich twórczości jako „teatru specjalnego”, choć w rzeczywistości stawał się on właśnie teatrem

16 Tomasz Rodowicz, Perspektywy 2015. Teatr poza teatrem [wypowiedź na temat Ogólnopolskiego Festiwalu Teatralnego Perspektywy 2015: Teatr poza teatrem] http:// retroperspektywy.com/pl/o-festiwalu/poprzednie-edycje/perspektywy2015/ (dostęp 15.10.2016).

17 Wg definicji Lecha Śliwonika; „Teatr dla życia [...], to wykorzystanie teatralnych metod pracy oraz możliwości tkwiących w produkcie teatralnym (spektaklu) dla osiągnięcia złożonych celów $\mathrm{w}$ dziedzinach nieartystycznych, a społecznie istotnych: edukacji, resocjalizacji, rehabilitacji, psycho i socjoterapii. Drugoplanowość zadań artystycznych nie wyklucza osiągnięcia poziomu wysokiej sztuki [...], ale nie stanowi celu głównego. Można by powiedzieć, że w tym przypadku teatr (praca teatralna) najbardziej się odrywa od sztuki i zbliża do »życia «”. Cyt. za: Lech Śliwonik, Teatr dla życia, „Scena. Miesięcznik poświęcony upowszechnianiu kultury teatralnej” 1999, nr 5, s. 17. 
„do spraw specjalnych”, specjalnych zadań dotyczących przemiany postrzegania przez widzów ich sztuki, a za jej pośrednictwem - siebie samych.

Podczas Perspektyw prezentowały się między innymi: Teatr 21 ze spektaklem Statek miłości; grupa teatru tańca - Kiosk Ruchu, która przedstawiła widowisko taneczne pt. Spotkanie (z udziałem osób po sześćdziesiątym roku życia) oraz monodram siedmioletniego Kacpra Olszewskiego (w reżyserii Przemysława Sowy), przybliżający temat wojny widziany oczami dziecka. Teatr Chorea, działając w swojej przestrzeni rozpoznawania nowej perspektywy teatru, wystawil spektakl (w reżyserii Adama Janusza Biedrzyckiego i Magdaleny Paszkiewicz) pt. Vidomi, który powstał we współpracy z młodzieżą słabowidzącą i niewidomą, a także monodram Oli Szałek pt. Przyjąć nie. Artystka, na swój autorski sposób, próbowała w monodramie wprowadzić widza w taki świat, jak go sama postrzega z perspektywy zespołu Aspergera ${ }^{18}$.

W trakcie tej wyjątkowej edycji festiwalu po zakończeniu każdego spektaklu odbywały się rozmowy widzów z artystami, których moderatorem był Piotr Olkusz. Jak podkreślał:

Każdy z pokazywanych spektakli powstał poza tradycyjnym modelem organizacji teatru, w nurtach, które szufladkujemy jako „teatr terapeutyczny”, „teatr amatorski”, „teatr zaangażowany społecznie”. Tylko że na Perspektywach nie oddawano się parametryzacji „terapeutyczności”, „amatorskości”, „zaangażowania”, lecz dowodzono, że to, co porusza, wzrusza i przemienia, wiąże się przede wszystkim z pierwszym członem tych złożonych nazw: $\mathrm{z}$ teatrem ${ }^{19}$.

\section{Retroperspektywy 2016, czyli wszystko - gra}

Piąta edycja Festiwalu odbyła się pod hasłem Teatr naznaczony muzyką i trwała od 25 do 28 sierpnia. Większość wydarzeń odbywała się w centrum festiwalowym położonym na terenie Art_Inkubatora. Wyjątek stanowily dwa koncerty: Iberyjskiej Orkiestry Perkusyjnej COETUS, która zagrała w Teatrze Muzycznym (dzięki uprzejmością jego dyrekcji, która zgodziła się użyczyć salę na okoliczność

18 Zespół Aspergera to rodzaj zaburzenia rozwoju mieszczącego się w spektrum autyzmu.

19 Piotr Olkusz, Teatr, przede wszystkim teatr. Festiwal Perspektywy, portal: teatralny.pl, http://teatralny.pl/recenzje/teatr-przede-wszystkim-teatr-festiwal-perspektywy,1074.html (dostęp: 15.10.2016). 
tego wydarzenia), oraz koncert Pieśni dla miasta zaprezentowany w przestrzeni miejskiej (pod kierownictwem muzycznym Tomasza Krzyżanowskiego).

Program Festiwalu składał się ze spektakli inspirowanych muzyką oraz z takich, w których muzyczny dźwięk stanowił główne tworzywo i wyznaczał ścieżkę komunikatu. O kształtowaniu przez organizatorów festiwalowego repertuaru tak pisał animator kultury i krytyk teatralny Mateusz Sidor:

Interesowały ich dzieła tworzone narracją dźwięku, a nie literackim budowaniem fabuły. W pracy niezależnych grup teatralnych równie ważny, co efekt końcowy jest twórczy proces. Aktorzy, tancerze czy muzycy podczas prób eksplorują możliwości własnego ciała, głosu, emocji, eksperymentują z muzyką. Taki teatr chce wywołać $\mathrm{w}$ widzu przeżycie, którym jest doświadczenie, nie proces intelektualny ${ }^{20}$.

Z okazji Festiwalu, po raz pierwszy w Polsce, wystąpili między innymi zaproszeni przez organizatorów: Gruziński Zespół Sakhioba (w koncercie tradycyjnej muzyki gruzińskiej), duet taneczny Igor \& Moreno (z brytyjskiego teatru The Place, ze spektaklem Idiot-syncras), Incubator Theatre z Izraela (ze spektaklem muzycznym The City) oraz Verity Standen (ze swoim niezwykłym performansem Hug).

Wśród wielu zagranicznych gości, których widowiska mogliśmy podziwiać na piątym Festiwalu, mieliśmy okazję zobaczyć także najnowszy spektakl wybitnego polskiego reżysera - Pawła Passiniego. Warto przypomnieć, że artysta współtworzył pierwsze Retroperspektywy w 2010 roku. Jak widać, mimo imponującej międzynarodowej obsady jakiej doczekało się łódzkie wydarzenie, Festiwal nie zapominał o potrzebie konfrontowania twórczości gości z silną polską reprezentacją. W ten sposób zespoły przyjeżdżające z różnych stron świata nie tylko mogły podzielić się swoją sztuką z gospodarzami, ale miały także zapewnioną możliwość poznania kierunków rozwoju i poszukiwań polskiej alternatywy teatralnej.

Gdy od 2011 roku zaczęłam uważnie przyglądać się działaniom Chorei, a potem także uczestniczyć w nich bezpośrednio, zyskiwałam coraz szerszy ogląd specyfiki Festiwalu. Jako świadek wydarzenia, jego wolontariuszka, a jednocześnie artystka występująca na scenie od trzeciej edycji Festiwalu, miałam okazję dobrze poznać jego strukturę i brać udział w większości prac organizacyjno-logistycznych. Tym swoim doświadczeniem także chciałabym się tu podzielić.

20 Mateusz Sidor, Retroperspektywy po raz piaty. Teatr offowy tradycja Łodzi, „Kronika miasta Łodzi” 2016, nr 3, s. 103. 
Kilka miesięcy przed rozpoczęciem Festiwalu, gotowy do pracy, stawia się cały zespół teatru oraz zebrana przez Annę Raczkowską specjalna grupa wolontariuszy. Każde wyjście do ludzi, w przestrzeń miasta, powinno nieść za sobą konkretne działanie, które pozostawi po sobie ślad: zaciekawi odbiorców, zaprosi ich do współobecności w sztuce - nie tylko w rolach widza i artysty.

Podczas drugiego Festiwalu w 2014 roku, gdy jego temat dotyczył kultury żydowskiej, akcja plakatowania była prowadzona jako happening. Do wydrukowanych wcześniej białych plakatów z czarnym napisem „RPS”, czyli skrótem utworzonym od nazwy festiwalu, domalowywano czerwonym sprejem gwiazdę Dawida. Skrót, przypominający nazwę jednego z łódzkich klubów piłkarskich, zamknięty w czerwonym symbolu, wzbudził sporo kontrowersji. W czasie przeprowadzania akcji plakatowania wielu przechodniów zwracało uwagę wolontariuszom, którzy dorysowywali symbol na plakacie, sądząc, że niszczą oni plakat lub są kibicami przeciwnej drużyny. W 2014 roku „sztuka promieniowała” z każdego plakatu Retroperspektyw. Miejsca, w których zawisły plakaty, były oznaczone jaskrawymi farbami - jak miejsca rzeczywistego promieniowania - a przestrzeń wokół nich była ogradzana specjalną taśmą, sugerującą pole bezpiecznej odległości. W trakcie przeprowadzania obu tych akcji wolontariusze ingerowali w przestrzeń miasta, zderzali się z ludźmi, tłumaczyli swoje działania i zapraszali na Festiwal.

Dwa tygodnie przed otwarciem III edycji Retroperspektyw, na skrzyżowaniu ulic Piotrkowskiej i Jaracza odbył się happening, który posłużył Chorei, by zaprosić do siebie mieszkańców Łodzi: obszar promieniowania wyznaczony został wówczas w samym sercu miasta ${ }^{21}$.

Szerzej o tym, na czym polega praca organizacyjna prowadzona w czasie $\mathrm{Fe}$ stiwali, rozmawiałam z Anną Raczkowską, która co roku koordynuje działania wolontariuszy.

\section{Wywiad z Anną Raczkowską 22}

EO: Jak wygląda „od kulis” praca na Retroperspektywach? Od kiedy rusza cała organizacja festiwalu, by zdążyć z przygotowaniem wszystkich działań?

AR: Ja zajmuję się biurem festiwalowym, centrum festiwalowym i jestem koordynatorką wolontariuszy. Patrząc od mojej strony, organizacja pracy zaczyna się od zebrania silnego zespołu wolontariuszy. Rekrutacja zaczyna się już na dwa miesiące przed rozpoczęciem festiwalu. W ciągu tych dwóch miesięcy

21 RETROPERSPEKTYWY 2014 SZTUKA PROMIENIUJE! - happening na ul.Piotrkowskiej 11 sierpnia 2014 roku, https://www.youtube.com/watch?v=aoR25DxJOYo (dostęp: 24.10.2016).

22 Wywiad przeprowadzony w 2016 roku, udostępniony za zgodą Autorki wypowiedzi. 
organizujemy kilka spotkań, na których wolontariusze przechodzą krótkie szkolenie. Podczas kilku wstępnych spotkań formujemy grupę ok. 50 osób. Pierwsze zebrania wolontariuszy odbywają się zwykle na półtora miesiąca przed samym festiwalem. Zazwyczaj zgłasza się 70-100 kandydatów, spośród których wybieramy tę 50-osobową grupę. Obecność tych ludzi jest niezbędną podstawą naszej pracy, np. przy obsłudze widza czy w biurze festiwalowym, które stanowi serce festiwalu. Często mówię, że to właśnie oni stanowią pierwszy front, bo osoby, które pracują z gośćmi, muszą być stale uśmiechnięte, dobrze poinformowane i gotowe na wszystko. A to jest bardzo ciężka praca. Na festiwal przyjeżdżają ludzie z całego świata, mówiący w różnych językach. Każdego z gości trzeba przywitać, oprowadzić po obiekcie, przekazać mu podstawowe informacje dotyczące spraw organizacyjnych i sprawić, by poczuł się dobrze. Jeszcze na szkoleniach przygotowujemy dla każdego gościa specjalną mapę, dzięki której będzie mógł swobodnie poruszać się po mieście i znaleźć drogę do swojego hotelu. Najtrudniej jest połączyć wszystkie te wydarzenia w jeden płynny cykl. Przyjmijmy, że dziennie w ramach festiwalu odbywa się pięć wydarzeń. Na każdym z nich musi być osobny zespół wolontariacki, zapewniający obsługę widza. Często bywa tak, że niektóre wydarzenia festiwalowe odbywają się poza siedzibą Art_Inkubatora, a tryb przemieszczania się pomiędzy biurem festiwalowym a miejscem spektaklu nie daje gwarancji, że zdąży się na czas. Niezbędne jest zatem wcześniejsze skonstruowanie dokładnego grafiku, by móc odpowiednio zadbać o komfort widza.

EO: Jaka najbardziej „awaryjna” sytuacja wydarzyła się podczas całego festiwalu?

AR: Podczas festiwali raczej nic dramatycznego się nie wydarzyło; choć bywało gorąco, zawsze udawało nam się przygotować wszystko na czas. Rzecz, jaką zawsze wspominam z uśmiechem, to nietypowe prośby naszych gości, na przykład okadzanie sali przed warsztatami jednego z mistrzów czy zamówienie masażysty na kilka godzin przed spektaklem dla jednego z artystów. Oczywiście można zaplanować festiwal, jednak bywają sytuacje, których nie jesteśmy w stanie przewidzieć, a którym musimy stawić czoło. W czasie edycji w 2014 roku jedna z krytyczek zaproszonych na Festiwal podczas podróży taksówką po Łodzi miała wypadek samochodowy. Ponieważ nie znała nikogo w naszym mieście, jedna $\mathrm{z}$ wolontariuszek została poproszona o zabranie $\mathrm{z}$ hotelu rzeczy należących do naszego gościa i o dostarczenie ich do szpitala. Można więc zaplanować próby, dostępność sali, odbiory gości z lotnisk itp., ale nigdy nie możemy być pewni, czy wszystko pójdzie zgodnie z planem. Festiwal jest jak organizm, jeśli go obudzimy i pozwolimy mu się rozpędzić, czasem możemy tracić nad nim kontrolę. Ważne w takich sytuacjach jest to, by zachować otwartość i potrafić się dostosować do sytuacji.

EO: Czy temat festiwalu w jakikolwiek sposób wpływa na sposób jego organizacji? 
AR: Oczywiście, w czasie edycji Perspektyw, podczas której temat Festiwalu skupiał się wokół zagadnienia inności, mieliśmy do czynienia z gośćmi z różnymi niepełnosprawnościami - i w tym przypadku również trzeba było zadbać o to, by wszyscy czuli się komfortowo. Podczas szkolenia do tego Festiwalu uczulaliśmy wolontariuszy na pewne aspekty obsługiwania gości, na które powinni szczególnie zwracać uwagę, np. upewnić się, czy scena i garderoba zostały przystosowane dla osób poruszających się na wózkach. Są to bardzo ważne rzeczy, o których trzeba pamiętać, zapraszając niepełnosprawnych artystów. Podczas całego festiwalu, jako koordynatorka wolontariuszy, organizuję codziennie odprawy. Pomagają one utrzymać kontrolę nad sytuacją i upewnić się, czy wszystko jest w porządku. Podczas odpraw każdy z wolontariuszy zdaje krótki raport z tego, co udało się już zrobić, a co jeszcze zostało do zrobienia.

EO: W trakcie festiwalu jesteś cały czas obecna. Czy masz możliwość obserwowania całego spotkania. Jak oceniasz atmosferę panującą na festiwalu?

AR: Atmosfera i otwartość całego wydarzenia zależy od organizatorów. Tutaj nic nie jest sztucznie kreowane, tak mi się przynajmniej wydaje. Oczywiście, są organizowane panele dyskusyjne czy spotkania po spektaklach, ale nikt nie bawi się tu w konferansjerkę, rozmowy przebiegają płynnie i naturalnie.

EO: Retroperspektywy mają w sobie niezwykłą lekkość. W trakcie całego festiwalu nie trafimy na sztywną konferencje przy stole, w towarzystwie kamer, i nie usłyszymy odczytywanych z kartek odpowiedzi na pytania.

AR: To właśnie widać po całej ekipie, która festiwale organizuje. Spotkanie nie polega jedynie na tym, że grupy teatralne się poznają, ale odbywa się wieczorami, gdy aranżowane są spontaniczne koncerty muzyczne - jamy, wtedy integrują się wszyscy. Nieważne czy ktoś jest aktorem, pracownikiem technicznym czy wolontariuszem - wolny czas spędzamy razem, dobrze się bawiąc i rozmawiając.

EO: Festiwal to święto, w którym momentami stajemy się wspólnotą - i to, jak mi się zdaje, wspominam najlepiej: gdy po całym dniu teatralnej uczty możemy razem usiąść i przeżyć wszystko jeszcze raz.

AR: Tak, festiwal jest naszym małym świętem w środku roku. Jest czymś, na co ciężko pracowaliśmy i czego wyczekiwaliśmy, a teraz, gdy właśnie jest ten czas, chce się korzystać z każdej jego minuty. Z każdym dniem zbliżającym nas do festiwalu byliśmy coraz bardziej ciekawi i głodni nowych doświadczeń.

Co roku jesteśmy gotowi na poszukiwanie nowych jakości w teatrze i na wymianę energii i doświadczeń. Wzajemne inspirowanie się podczas tych kilku dni czasami może zaowocować dalszą współpracą. Bywa tak, że po pobycie na festiwalu zawiązują się nowe znajomości i pojawiają się propozycje organizowania wspólnych warsztatów lub tworzenia razem spektaklu. Grupy wolontariuszy, które angażują się co roku w pomoc przy festiwalu, w większości zostają na kolejne edycje. Zespół czuwa i asystuje przy różnych działaniach podczas całego 
festiwalu. Doba wolontariusza często trwa od godziny ósmej rano do nawet trzeciej w nocy; mimo intensywności działań mają oni możliwość uczestnictwa w niektórych wydarzeniach, również jako widzowie.

Podczas przygotowań do kolejnej festiwalowej edycji udało mi się porozmawiać z uczestniczką drugiego Festiwalu - Kają Kopytkiewicz.

\section{Wywiad z Kają Kopytkiewicz 23}

EO: Na czym, według ciebie, polega wyjątkowość festiwalu Retroperspektywy?

KK: Ważne jest dla mnie to, że jest „niszowy”, i że jest blisko ludzi. Dlatego że są takie festiwale, na których widz ma poczucie: „chyba tu nie pasuję”, albo: „to chyba niekoniecznie dla mnie”. A to jest festiwal, który jest bardzo „dla ludzi”, nikt nie czuje się tu skrępowany; nawet gdy zobaczy trudny spektakl, to w takiej atmosferze dużo łatwiej jest wszystko przyswoić.

EO: Czy będąc wolontariuszką, miałaś możliwość zapoznać się z tym, co artystycznie ma do zaoferowania festiwal?

KK: Tak, choć brałam udział w festiwalu już jakiś czas temu, pamiętam, że te spektakle, które miałam okazję zobaczyć, były na wysokim poziomie. Uczestniczyłam w festiwalu w roku 2012, wtedy centrum festiwalowe mieściło się w Willi Grohmana.

EO: $\mathrm{W}$ takim razie: czy mogłabyś powiedzieć, w jaki sposób zmiana przestrzeni ma wplyw na organizacje biura festiwalowego? Bo usytuowanie festiwalu w przestrzeni miejskiej też jest istotnym zagadnieniem.

KK: Festiwal stwarzał wyjątkową możliwość, żeby tchnąć życie w te przestrzenie, które były nieużywane - to było bardzo ciekawe. Panowała tam bardzo swobodna atmosfera, ponieważ - dla potrzeb stworzenia biura - mogliśmy zaadaptować miejsce po swojemu. Bardzo mile też wspominam koncerty, które co wieczór odbywały się na powietrzu.

\section{Moja perspektywa}

Retroperspektywy są wydarzeniem niemającym formy „nadętego” spotkania $\mathrm{z}$ mediami, podejmowanego $\mathrm{w}$ celu promocji konkretnej teatralnej marki. Rozmowy nie są tu prowadzone w konwencji konferencyjnej, lecz są żywą wymianą

23 Wywiad przeprowadzony w 2016 roku, udostępniony za zgodą Autorki wypowiedzi. 
myśli, przepływem stanowisk wobec świata, sztuki i celu teatru we współczesnym świecie. Na festiwal przyjeżdżają grupy z całego świata, niekiedy udaje się podjąć z nimi współpracę również poza festiwalem. Bywało tak, że Chorea - wspólnie z zespołem będącym gościem festiwalu - tworzyła nowy spektakl lub prowadziła wspólne warsztaty; więc to nie jest tak, że grupa przyjedzie, wystąpi i kontakt pomiędzy teatrami się urwie.

Za każdym razem gdy Chorea zaprasza grupę pochodzącą z innej kultury, tworzy się w czasie spotkania prawdziwa „teatralna bomba”, której jestem bardzo ciekawa. Gdy w 2016 roku na festiwal został zaproszony chór z Gruzji i podczas nocnego koncertu artyści gruzińscy śpiewali pieśni wspólnie z Młodym Chórem Chorei, w bardzo spontaniczny sposób powstało niesłychanie piękne widowisko. Przepływ i wymiana ponad granicami gwarantuje poszerzenie perspektywy. Im bardziej różnorodny zestaw artystów, tym większe stoi przed nami wyzwanie dotyczące zrozumienia ich sztuki. Dzisiaj zarówno w relacjach międzyludzkich, jak i we współczesnym teatrze budujemy podziały i wzajemnie się szufladkujemy. Tworzymy granice, ograniczając przestrzeń, w jakiej działamy, dzielimy się na grupy, specjalizacje i nurty, przez co zamykamy przed sobą możliwość dialogu. Festiwale teatralne, które tworzą wspaniałą okazję do spotkania, coraz częściej działają jedynie w środowiskach określonych grup czy gatunków teatrów (teatry lalkowe, muzyczne, taneczne, terapeutyczne), przez co stają się bardziej przeglądami niż spotkaniami i coraz bardziej zamykają się we własnych kręgach. Sama kilkukrotnie miałam okazje zderzyć się z tym, jak bardzo jesteśmy pozamykani, nawet na poziomie pracy z osobami z niepełnosprawnościami. Dopiero wtedy, gdy zaczyna się intensywnie razem pracować, zyskuje się możliwość prawdziwego otwarcia, zrozumienia: to tak samo, jakbyś spotykał inną kulturę, w której chcesz zaistnieć.

Trudno przewidzieć, jakie hasło będzie przyświecać kolejnym Retroperspektywom: zależeć ono będzie w pełni od bieżącej potrzeby teatru. Temat „przychodzi sam”, ponieważ jako artyści odnosimy się przez sztukę do rzeczywistości, w której żyjemy. Teatr jest instytucją bardzo wrażliwą na sprawy społeczne i reaguje na każdy wysyłany przez ludzi impuls, na każdy lęk czy nadzieję. Działania Chorei, jak i gości naszego Festiwalu, w znacznej mierze łączą się z aktualnymi uwarunkowaniami tak zwanego kontekstu społecznego. Spektakle są wypadkową tego wszystkiego, co się dzieje właśnie w tej chwili, czyli bezpośrednio odnoszą się do sytuacji, w jakiej się znajdujemy my sami lub w jakiej znajdują się ludzie, z którymi pracujemy. Dlatego organizatorzy pragną - obok głównego nurtu festiwalu - utrzymać także cykl wydarzeń towarzyszących, zgodnych tematycznie z tym zasadniczym nurtem, ale aranżującym takie spotkania jak Perspektywy 2015. Miałyby to być wydarzenia odbywające się sukcesywnie - co kwartałlub co dwa miesiące. Taka koncepcja rozwoju Festiwalu pomogłaby zachować nawiązane już kontakty i podtrzymać ich ciągłość, a dzięki temu ludzie mogliby przyzwyczaić się do swojej stałej (i nieodzownej im) 
obecności Festiwalu. Główny nurt Retroperspektyw pozostałby zatem międzynarodowym festiwalem, który dotyczyłby poszukiwań nowego języka teatru i rozwiązań artystycznych niezbędnych do skonstruowania nowego, energetycznego komunikatu w sztuce. „Małe perspektywy” będą najpewniej rozbijane na jeszcze mniejsze - za to uderzające $\mathrm{z}$ większą częstotliwością - ogólnopolskie spotkania, które będą dotyczyły działalności teatrów usytuowanych w trudnych kontekstach społecznych.

Festiwal ma swoją osobną, unikatową formę, wyraźnie odróżniającą go od podobnych wydarzeń artystycznych, na których najczęściej ogląda się najnowsze dokonania najbardziej znanych teatrów albo organizuje przeglądy spektakli reprezentujące działania teatralne utrzymane w jednym, ściśle określonym nurcie. Wydaje mi się, że piękno i wartość spotkania tkwi w różnorodności perspektyw poznawczych, jakie to spotkanie wyzwala i prowokuje. W przypadku Festiwalu żywość i kreatywność zapewnia zmiana wiodących tematów, przemieniających się z każdą jego edycją. Ta przemiana znaczeń, poszukiwań, określa charakter Festiwalu i każdemu z nich nadaje odrębność, a jednocześnie pozwala zachować tę samą postawę wobec kolejnych aranżowanych wydarzeń $\mathrm{i}$ - przede wszystkim - wobec zaproszonych do udziału w nich ludzi. I tę samą energię, z jaką podejmuje się kolejne wyzwania.

Niech w podsumowaniu mojej wypowiedzi jeszcze raz wybrzmi głos Tomasza Rodowicza:

Będziemy zawsze szukać w tym naszym festiwalu rzeczy wyjątkowych, które normalnie nie pojawilyby się w Polsce, które inaczej by się nie spotkały, nie skonfrontowały i nie zderzyły ze sobą. Wypowiedzi teatralne, które są najbardziej odważne, a które nie muszą koniecznie być z pierwszych stron gazet i mieć najlepszych recenzji. Zależy nam na tych, które mają własną unikatową i niepowtarzalną wypowiedź teatralną, żywą, energetyczną i nie o byle czym. O czymś, co się wiąże albo z pewnym przesłaniem, albo z sytuacją aktorów, albo z sytuacją społeczną, w której oni działają, w której walczą o coś; albo istnieją w sytuacjach, w których się konfrontują z tym, co zewnętrzne i próbują zdefiniować swoją obecność w sztuce, w swoim w niej funkcjonowaniu. Chcemy wspierać tych, którzy pozostają ciekawi. Zawsze będziemy szukać tych form i takich teatrów, które wnoszą to, co jest najważniejsze: pewnego rodzaju nadzieję, jasność. We współczesnej rzeczywistości otacza nas tak dużo ciemnego i złego, tego wszystkiego, co się w świecie dzieje - poprzez wojny, dyskryminacje, lęki, fobie i budzące się w człowieku różnego rodzaju demony. Teatr powinien służyć tej jasnej stronie życia ludzkiego i takiej będziemy zawsze bronić24.

$24 \mathrm{Z}$ wywiadu przeprowadzonego przez autorkę w 2016 roku. 
Chciałabym dodać, że dziś - po kilku latach od chwili powstania tego artykułu - Teatr Chorea planuje kolejne edycje festiwalu, za każdym razem poszukując nowych teatralnych jakości i dotykając aktualnych tematów, które artyści oraz widzowie wspólnie problematyzują. Festiwal z edycji na edycję się rozrasta, a w jego organizację angażuje się cały zespól, jednocześnie przygotowując co najmniej jedną premierę, jaka będzie prezentowana podczas każdej Retroperspektywy. Przedsięwzięcie, mimo jego rosnącego wymiaru i nieustannego wzbogacania programu, nie traci „offowego pazura”. Artyści zapraszani na festiwal wybierani są nie ze względu na swoją popularność, lecz z powodu przystawania ich twórczości do idei, które przyświecają Chorei w codziennej pracy. Myślę, że śmiało można zaryzykować stwierdzenie, że jest to jeden z nielicznych tak pomyślanych festiwali w Polsce: festiwal, który promuje inkluzywne podejście do budowania twórczej wypowiedzi, prowadzi liczne spotkania z publicznością, zachęcając do dialogu na temat teatru, oferuje bogate warsztaty merytoryczne i praktyczne oraz wspiera młode rozwijające się zespoły. To wszystko udaje się osiągnąć bez ogromnego zaplecza organizacyjnego czy finansowego, jedynie dzięki zaangażowaniu niewielkiej grupy stanowiącej zespół Teatru Chorea, którego członkowie potrafią łączyć wiele funkcji. W czasie mojej pracy przy kilku już edycjach Festiwalu Retroperspektywy oraz Perspektywy mogłam z bliska obserwować działania aktorów i organizatorów tego wydarzenia, zdobywać doświadczenie i uczyć się sposobów funkcjonowania teatrów nieinstytucjonalnych - tak w ich codziennych działaniach, jak i przy okazji organizacji dużych wydarzeń artystycznych. Sądzę, że sekretem powodzenia Retroperspektyw jest fakt, iż wspóltworzą ten festiwal ludzie myślący wielowymiarowo i właśnie dzięki takiej ich cesze możemy podziwiać tu wypowiedzi o rzeczywistości formułowane z bardzo wielu perspektyw, ujmowane w różne języki współczesnej sztuki - przy okazji każdego spotkania od nowa.

\section{Bibliografia}

Grotowski Jerzy, Ku teatrowi ubogiemu, przeł. z ang. Grzegorz Ziółkowski, red. Leszek Kolankiewicz, Instytut im. Jerzego Grotowskiego, Wrocław 1968.

Ilska Paulina, Stawiać widza przed ściana, „Arterie” 2010, nr 2.

Olkusz Piotr, Teatr, przede wszystkim teatr. Festiwal Perspektywy, portal: teatralny.pl, http://teatralny.pl/recenzje/teatr-przede-wszystkim-teatr-festiwal-perspektywy,1074.html (dostęp: 15.10.2016).

Rodowicz Tomasz, 10 Lat Chorei... [wypowiedź na temat Międzynarodowego Festiwalu Teatralnego Retroperspektywy 2014], strona Festiwalu, http://retroperspek- 
tywy.com/pl/o-festiwalu/poprzednie-edycje/retroperspektywy2014/ (dostęp: 10.10.2016).

Rodowicz Tomasz, Perspektywy 2015. Teatr poza teatrem [wypowiedź na temat Ogólnopolskiego Festiwalu Teatralnego Perspektywy 2015: Teatr poza teatrem], http:// retroperspektywy.com/pl/o-festiwalu/poprzednie-edycje/perspektywy2015/ (dostęp: 10.10.2016).

Rodowicz Tomasz, Retroperspektywy 2012 [wypowiedź programowa na temat Międzynarodowego Festiwalu Teatralnego Retroperspektywy 2012], strona Festiwalu, http://retroperspektywy.com/pl/o-festiwalu/poprzednie-edycje/retroperspektywy2012/ (dostęp: 10.10.2016).

Rodowicz Tomasz, Retroperspektywy 2014 [wypowiedź programowa na temat Międzynarodowego Festiwalu Teatralnego Retroperspektywy 2014], strona Festiwalu: http://retroperspektywy.com/pl/o-festiwalu/poprzednie-edycje/retroperspektywy2014/ (dostęp: 10.10.2016)

Rodowicz Tomasz, tekst programowy: Festiwal Teatralny Retroperspektywy 2010, http://retroperspektywy.com/pl/o-festiwalu/poprzednie-edycje/retroperspektywy2010/ (dostęp: 10.10.2016).

Sidor Mateusz, Retroperspektywy po raz piaty. Teatr offowy tradycja Łodzi, „Kronika miasta Łodzi” 2016, nr 3.

Śliwonik Lech, Teatr dla życia, „Scena. Miesięcznik poświęcony upowszechnianiu kultury teatralnej" 1999, $\mathrm{nr} 5$.

Woźniak Grzegorz, Retro/per/spektywy [dział: Czasopisma, Festiwale, Nagrody, Lamus, Życie Literackie], „Lampa” 2020, nr 10.

\section{Netografia}

(dostęp: 10.10.2016)

http://retroperspektywy.com/pl/

http://www.chorea.com.pl/

https://www.youtube.com/watch?v=aoR25DxJOYo 